\title{
Social Entrepreneurship: Strategic Development in Croatia
}

\author{
Marko Kolaković * \\ Mladen Turuk* \\ Ivan Turčić*
}

\begin{abstract}
Social Entrepreneurship is an area of entrepreneurship and economics in general that have become more and more popular in the last 30 years across the whole globe. However, the topics related to social entrepreneurship came in focus in Croatia during the past years due to developing and adopting the Strategy for the Development of Social Entrepreneurship in the Republic of Croatia for the period from 2015 to 2020. This paper will provide an overview of the relevant definitions of social entrepreneurship, social entrepreneur and social enterprise (with reference to the Strategy). The aim of this paper is to analyse the strategic framework for development of social entrepreneurship in Croatia and finally, to propose the direction of development of social entrepreneurship in Croatia in the future.
\end{abstract}

Keywords: social entrepreneurship in Croatia; national strategy of social entrepreneurship; strategic development

JEL Classification: L26, L31

\section{Introduction}

Social Entrepreneurship is an area of entrepreneurship and economics in general that have become more and more popular in the last 30 years across the whole globe. William Bill Drayton is the person who first defined the term "social entrepreneurship" in the 1980s (Škrtić \& Mikić, 2011) and we could classified him as the godfather of social entrepreneurship. Bill Drayton also founded Ashoka - Innovators of the Public in 1980 based on the idea that the most powerful force for good in the world is a social entrepreneur: a person driven by an innovative idea that can help correct an entrenched global problem. The world's leading social entrepreneurs pursue system-changing solutions that permanently alter existing patterns of activity. Begin-

\footnotetext{
* Marko Kolaković, Mladen Turuk and Ivan Turčić are at Department of Managerial Economics, Faculty of Economics and Business, University of Zagreb, Zagreb, Croatia.
} 
ning in India in 1981, Ashoka started identifying and supporting the world's leading social entrepreneurs who have ideas for far-reaching social change. It started by first distilling their unique qualities and pioneering a rigorous global system for vetting and electing them to the Ashoka Fellowship. Ashoka today has 3,300 fellows and alumni working in 93 countries (Ashoka).

Along with the aforementioned Drayton, the most famous social entrepreneur is certainly Muhammad Yunus who with Grameen Bank received the Nobel Peace Prize in 2006. (Yunus et al., 2010) Yunus launched the Grameen Bank with a core mission of encouraging the poorest people in the world to get out from the vicious cycle of poverty by providing them with access to financial services - microcredit. Banks in the traditional system have been reluctant to lend money to anyone unable to give some form or other of security. Traditional banks have reluctant to lend money to anyone unable to present some collateral. Grameen Bank, on the other side, works on the principle and believe that even the poorest people can get along with own financial affairs and escape from poverty. The Bank would help poor people by providing them the loan and giving some basic education about how to manage personal finance (Bayulgen, 2008, Nobel Prize).

In the Republic of Croatia, interest for social entrepreneurship has increased in last decade but unfortunately, there was a lack of institutional support from government to create the national strategy for development of social entrepreneurship. Despite some legal forms in Croatian national legislation that enable to establish enterprises with social activities, there is currently no specific law for defining or regulating social enterprise in Croatia. However, in 2015, social entrepreneurship came in focus due to developing and adopting the Strategy for the Development of Social Entrepreneurship in the Republic of Croatia for the period from 2015 to 2020 whose aim is to give a new massive impulse for developing strategic and financial framework for social enterprises.

This paper will provide an overview of the relevant definitions of social entrepreneurship, social entrepreneur and social enterprise (with reference to the Strategy). The aim of this paper is to analyse the strategic framework for development of social entrepreneurship in Croatia and finally, to propose the direction of development of social entrepreneurship in Croatia in the future.

\section{The Definition of Social Entrepreneurship}

As it was already mentioned in the introduction social entrepreneurship is term that has appeared in the 1980s. Although more than 30 years have passed since then, there is still no unique definition of social entrepreneurship that would satisfy all involved parties. Despite the various definitions and its meanings, the link to all definition is social mission. That social mission encourages social entrepreneurs to a social acting 
on community and starting a social venture (Urbano et al., 2017.; Leadbeater 1997). According to Bornstein \& Davis (2010), the most widely cited definition was offered by Greg Dees, who is often referred to as the father of social entrepreneurship education. Dees $(2001 ; 4)$ attributed to social entrepreneurs a task to "play the role of change agents in the social sector, by:

a) Adopting a mission to create and sustain social value (not just private value),

b) Recognizing and relentlessly pursuing new opportunities to serve that mission,

c) Engaging in a process of continuous innovation, adaptation, and learning,

d) Acting boldly without being limited by resources currently in hand, and

e) Exhibiting a heightened sense of accountability to the constituencies served and for the outcomes created."

Social entrepreneurs, he explains, create public value, pursue new opportunities, innovate and adapt, act boldly, leverage resources they do not control, and exhibit a strong sense of accountability (Bornstein \& Davis 2010).

Fowler (2000; 649) argues that "social entrepreneurship is the creation of viable (socio-) economic structures, relations, institutions, organisations and practices that yield and sustain social benefits" while Lasprogata \& Cotten $(2003$; 69) believe that term social entrepreneurship stands for "non-profit organizations that apply entrepreneurial strategies to sustain themselves financially while having a greater impact on their social mission." Weerawardena \& Mort (2006; 25) likewise argue that social entrepreneurship occurs in not-for-profit organisation in "context aimed at delivering social value through the exploitation of perceived opportunities". On the other side Austin, Stevenson \& Wei-Skillern (2006; 2) present social entrepreneurship "as innovative, social value creating activity that can occur within or across the non-profit, business, or government sectors." Nicholls also describes social entrepreneurship phenomenon more broadly $(2006 ; 5)$; "social entrepreneurship represents an umbrella term for a considerable range of innovative and dynamic international praxis and discourse in the social and environmental sector." Mair \& Marti (2006; 37) define social entrepreneurship as a process "involving the innovative use and combination of resources to pursue opportunities to catalyse social change and/or address social needs."

Peredo \& McLean (2006; 64) argue that social entrepreneurship is "exercised where some person or group: (1) aim(s) at creating social value, either exclusively or at least in some prominent way; (2) show(s) a capacity to recognize and take advantage of opportunities to create that value ("envision"); (3) employ(s) innovation, ranging from outright invention to adapting someone else's novelty, in creating and/ or distributing social value; (4) is/are willing to accept an above-average degree of risk in creating and disseminating social value; and (5) is/are unusually resourceful in being relatively undaunted by scarce assets in pursuing their social venture".

Zahra, Gedajlovic, Neubaum \& Shulman (2009; 522) claim that social entrepreneurship "encompasses the activities and processes undertaken to discover, define, 
and exploit opportunities in order to enhance social wealth by creating new ventures or managing existing organizations in an innovative manner". Bacq \& Janssen (2011; 376) define social entrepreneurship as "the process of identifying, evaluating and exploiting opportunities aiming at social value creation by means of commercial, market-based activities and of the use of a wide range of resources". Choi \& Majumdar $(2014 ; 372)$ emphasize that entrepreneurship should be conceptualized as cluster concept. "Conceptualizing social entrepreneurship as a cluster concept implies that social entrepreneurship is a representation of the combined quality of certain sub-concepts, i.e., social value creation, the social entrepreneur, the SE organization, market orientation, and social innovation". Above presented definitions and descriptions of social entrepreneurship were found in the literature from the most relevant representatives of the academic community with an interest in social entrepreneurship. It is obvious that there is no consensus in defining social entrepreneurship and especially its boundaries.

Numerous organizations in the world have also recognized the phenomenon of social entrepreneurship and they bring their own definition of the term. For an instance, the Organisation for Economic Co-operation and Development (OECD, 2010; 188) defines social entrepreneurship "as entrepreneurship that aims to provide innovative solutions to unsolved social problems. Therefore it often goes hand in hand with social innovation processes, aimed at improving people's lives by promoting social changes". Schwab Foundation (2005) emphasizes that social entrepreneurship "is about applying practical, innovative and sustainable approaches to benefit society in general, with an emphasis on those who are marginalized and poor. A term that captures a unique approach to economic and social problems, an approach that cuts across sectors and disciplines grounded in certain values and processes that are common to each social entrepreneur, independent of whether his/ her area of focus has been education, health, welfare reform, human rights, workers' rights, environment, economic development, agriculture, etc., or whether the organizations they set up are non-profit or for-profit entities."

When we are talking about the official definition of social entrepreneurship in the Republic of Croatia, it did not exist until 2015. Government of the Republic of Croatia in 2015 adopted the Strategy for the Development of Social Entrepreneurship in the Republic of Croatia for the period from 2015 to 2020. This Strategy is bringing the official definition of social entrepreneurship that is implemented in national strategic document for the first time. The Strategy (Government of the Republic of Croatia 2015; 7) defines social entrepreneurship as "a business based on the principles of social, environmental and economic sustainability, in which generated profit is entirely or largely reinvested for the benefit of the community." The definition is based on the triple bottom line (Slaper \& Hall, 2011) - the accounting framework that incorporates three dimensions of performance and sustainability: social, environmental (or ecological) and financial (or business) and on reinvesting the generated profit from 
socio-entrepreneurial activity in further accomplishing a social mission. Furthermore, definition is also in compliance with the European Commission and its Social Business Initiative $(2011 ; 2)$ in which social enterprise is defined ,,as an operator in the social economy whose main objective is to have a social impact rather than make a profit for their owners or shareholders. It operates by providing goods and services for the market in an entrepreneurial and innovative fashion and uses its profits primarily to achieve social objectives. It is managed in an open and responsible manner and, in particular, involve employees, consumers and stakeholders affected by its commercial activities." The concept of social enterpeneurship in Croatia is defined more broadly due to the lack of implicit definition of sector (non-profit, business, or government sector) where social entrepreneurship may occurs. The Strategy is also providing the nine criteria for defining social entrepreneurs in Croatia and it is important to analyse criteria and definition together due to their connection. Therefore, criteria will be listed and analyse in the next part of this paper.

\section{Defining of Social Entrepreneur and Types of Social Entrepreneur}

The main distinction between social and traditional entrepreneur is the purpose what is the main goal for entrepreneur. While a traditional entrepreneur wants to maximize profit or owner's wealth, a social entrepreneur is aimed to maximize some form of social impact. Both types of entrepreneurs are facing some problems during their entrepreneurial activity but social entrepreneurship is often more challenging due to tackling the problems for which market solutions have not yet been demonstrated (Bornstein \& Davis 2010).

Abu-Saifan $(2012 ; 25)$ argue that social entrepreneur is "a mission-driven individual who uses a set of entrepreneurial behaviours to deliver a social value to the less privileged, all through an entrepreneurially oriented entity that is financially independent, self-sufficient, or sustainable." His definition merges four features that distinguish social entrepreneur from other form of entrepreneurs. Social entrepreneurs: "a) are mission-driven. They are dedicated to serve their mission of delivering a social value to the underserved; b) act entrepreneurially through a combination of characteristics that set them apart from other types of entrepreneurs (see Table 1); c) act within entrepreneurially oriented organizations that have a strong culture of innovation and openness; d) act within financially independent organizations that plan and execute earned-income strategies. The objective is to deliver the intended social value while remaining financially self-sufficient." 
Table 1: Unique and common characteristics of profit-oriented entrepreneurs and social entrepreneurs

\begin{tabular}{|l|l|l|}
\hline $\begin{array}{c}\text { Unique characteristics of the profit- } \\
\text { oriented entrepreneur }\end{array}$ & \multicolumn{1}{|c|}{$\begin{array}{c}\text { Characteristics common to both } \\
\text { types }\end{array}$} & $\begin{array}{l}\text { Unique characteristics of the social } \\
\text { entrepreneur }\end{array}$ \\
\hline $\begin{array}{l}\text { - High achiever } \\
\text { - Risk bearer }\end{array}$ & - Innovator & - Mission leader \\
- Organizer & - Initiative taker & - Emotionally charged \\
- Strategic thinker & - Leader & $\begin{array}{l}\text { - Change agent } \\
\text { - Opinion leader }\end{array}$ \\
- Value creator & - Opportunity alert & - Social value creator \\
- Arbitrageur & - Persistent & - Socially alert \\
& - Committed & - Manager \\
& & - Visionary \\
\hline
\end{tabular}

Source: Abu-Saifan (2012)

As it can be seen from the above table both social and profit-oriented entrepreneurs have some similar characteristics: both types of entrepreneurs require commitment, initiative, dedication, leadership and persistence. Their character and ability for business administration are notably similar with the difference in their primary objectives and goals.

There are numerous classifications of social entrepreneurs in the literature, but certainly the most cited typology of social entrepreneurs is from Zahra et al. (2009). Zahra et al. provided classification of social entrepreneurs in three major types: social bricoleur, social constructionist and social engineer derived from theory of Hayek, Kirzner \& Schumpeter.

\section{Social Bricoleur}

The first type of social entrepreneurship, which Zahra et al. labelled the social bricoleur, draws on Hayek's view of entrepreneurship as a largely localized undertaking (Smith \& Stevens 2010, according to Hayek 1945). Social bricoleur is type of social entrepreneur focused on acting towards the local community and solving social issues and satisfying needs of the local community. His scale of acting is small and local in scope although this is an advantage due to quick time of respond and ability of detecting local problems. The main difference from other types of social entrepreneurs is that social bricoleur does not depend on numerous external or specialized resources for achieving their goals and objectives. Therefore, he just relies on readily available resources and improvisation which is a major cause that prevents social bricoleurs from providing massive impact on society and addressing larger needs (Zahra et al., 2009.). Di Domenico et al. $(2010 ; 698)$ developed a conceptual framework of social bricolage in the context of social entrepreneurship. Their proposed principles and processes of social bricolage are: "a) making do with limited resources available 
and creating something from nothing for a social end; b) refusal to be constrained by limitations imposed by pervading environmental constraints in pursuit of social goal c) improvisation to enable active pursuit of social purpose; d) creation of social value; e) stakeholder participation; f) persuasion of other significant actors to leverage acquisition of new resources and support".

\section{Social Constructionist}

Theoretical inspiration for social constructionist came from Krizner. Sunley and Pinch (2012; 116, according to Zahra et al., 2009) argue that some social entrepreneur could move from local social bricoleur to ,a constructionist position that produces broader social reforms and ventures that can be scaled up and transferred across localities". The needs that social constructionists identify and seek are usually aimed on creating social wealth. Social constructionists also "build, launch and operate ventures which tackle those social needs that are inadequately addressed by existing institutions, businesses, NGOs and government agencies" (Zahra et al., 2009; 525). The major advantage of this type of social entrepreneur is solution that could be applicable and expandable to solve an issues occurring in different contexts (Smith \& Stevens 2010).

\section{Social Engineer}

Third type of social entrepreneur is inspired by Schumpeter and it is called social engineer. Social engineers are entrepreneurs who identify and tackle systematic problem within the social systems and structures and address them by providing revolutionary solutions and changing whole society. They want to replace existing national, transnational and global institutions with more social efficient ones and that is the reason why they are often seen as a threat from establish institutions. Their scale of acting is very large that is national to international in scope and which seeks to create durable structures that will challenge existing order (Zahra et al., 2009). Wulleman $\&$ Hudon (2016) point out that social engineers are playing the main role in process of social change, reshaping established institutions from outside of the existing system. The example of social engineer is one of the most famous social entrepreneurs, aforementioned Muhammad Yunus (Zahra et al., 2009; Smith \& Stevens 2010).

\section{The Strategic Development of Social Entrepreneurship in Croatia}

As it was already mentioned, social entrepreneurship came in focus in Croatia due to developing and adopting the Strategy for the Development of Social Entrepreneur- 
ship in the Republic of Croatia for the period from 2015 to 2020. This Strategy is the fundament of strategic development of social entrepreneurship in Croatia and will be further analysed in this part of paper.

Prior to adopting the Strategy for the Development of Social Entrepreneurship, National Strategy for the Creation of an Enabling Environment for Civil Society Development (2012-2016) and Strategy for Combating Poverty and Social Exclusion in the Republic Croatia (2014 to 2020) were two national strategic documents that mentioned social entrepreneurship in a context of strategic development. National Strategy for the Creation of an Enabling Environment for Civil Society Development (2012-2016) adopted by the Government of the Republic of Croatia on 12 July 2012 is the national strategic document which prescribed measures intended for: a) encouraging social entrepreneurship development in civil society organisations; b) ensuring the sustainability of social entrepreneurship initiatives of civil society; c) raising public awareness about the role of CSOs in social and economic development (Government of the Republic of Croatia, 2012). The Strategy for Combating Poverty and Social Exclusion in the Republic Croatia (2014 to 2020) points out that social entrepreneurship can be a key solution for combating poverty and social exclusion. Thus, Strategy emphasizes the encouragement of social entrepreneurship as a strategic activity in a field of employment (Government of the Republic of Croatia, 2014).

The Strategy for the Development of Social Entrepreneurship in the Republic of Croatia $(2015 ; 8)$ provides for the first time the criteria for defining social entrepreneurs in Croatia:

a) Social entrepreneur achieves a balanced social, environmental and economic goal of business;

b) Social entrepreneur is engaged in the production and transport of goods or services or art that generate revenues on the market, and has a favourable impact on the environment, contributes to the development of the local community and society at large;

c) Social entrepreneur create new value and ensures financial sustainability in a way that three years after the establishment of business at least $25 \%$ of the income is planned to be or is realized by its entrepreneurial activities;

d) Social entrepreneur uses at least $75 \%$ of the profit to invest in the development of its activities and the achievement of its primary business objective;

e) Social entrepreneur is characterized by voluntary and open membership and a high degree of business autonomy;

f) The Republic of Croatia, local and territorial (regional) self-government or a public authority may not be the sole founder of the social enterprise;

g) Social entrepreneur is characterized by participatory decision-making process (involvement of stakeholders in transparent and accountable management), or the decision making is not exclusively related to the ownership or membership 
structure but includes other stakeholders: employees, members, consumers, and other relevant organizations;

h) Social entrepreneur monitors and evaluates its social, economic and environmental impact. Results of the evaluation are used in the planning and future steps to increase the impact of the business.

i) In the case where social entrepreneur ceases to perform its activity, the assets (apart from the membership fees in cooperatives), after obligations towards creditors are fulfilled and losses from the previous period covered, must be transferred to the ownership of another social enterprise with same or similar goals or to the local community and local (regional) government which will use it for the development of social entrepreneurship.

Presented criteria are in accordance with criteria of European Commission and Thompson's characteristics (Thompson; 2008;153, taken from Thompson \& Doherty; 2006) that determine the social enterprise. The characteristics of social enterprise are the following: "a) It has a social purpose; b) Its assets and wealth are used to create community benefit; c) It pursues this with (at least in part) trading activities. If it delivers services to clients which are paid for by a third party, as distinct from direct sales to a customer, this is still regarded as trading; d) Profits and surpluses are reinvested in the business and community rather than distributed to shareholders; e) Employees (or members) have some role in decision making and governance; f) The enterprise is held accountable to both its members and a wider community; g) There is either a double or triple bottom-line paradigm with an acceptable balance of economic, social and possibly environmental returns - which are audited". Vidović \& Baturina (2016) consider that many of Strategy's criteria are formulated as wide requirements rather than as clear defined indicators. They suppose that there will be some certain difficulties to evaluate and monitor criteria, particularly as regards the requirements related to measuring impact. Šimleša et al. (2016) also point out the eighth criteria as a problematic and that some of the criteria within the Strategy will probably have to at least be further clarified so that they could be applied in the practice as easily as possible.

One of activity prescribed in the Strategy is activity 1.5 Establishing a Unique Social Entrepreneurs Register, Developing Criteria and Rules for Recognizing Social Entrepreneurs. Each entrepreneur and/or enterprise that fulfils Strategy's criteria will be registered in Social Entrepreneurs Register for the period of three years. After three years, a social enterprise can again apply for registration in Register or will be deleted. Social Entrepreneurs Register will be an official list of social entrepreneurs in the Republic of Croatia and will be used as a basis for applying for financial supports and grants for its members. According to the Strategy, the implementation deadline for activity 1.5 was 2 nd Quarter of 2016. Unfortunately, at the time of writing this paper, the activity 1.5 has not yet been implemented (2nd Quarter of 2017). Due to this reason, it is still unknown the exact number of social enterprises in the 
Republic of Croatia. However, consulted stakeholders (in a project of mapping social enterprises in Croatia for the European Commission) assume that there are approximately from 40 to 210 social enterprises in the Republic of Croatia (ICF Consulting Services 2014).

The most of social enterprises operate within civil society organisations (whether by establishing a separate legal person, most often a cooperative or a company, which returns its profit to the CSO which founded it; or by organising a social entrepreneurship initiative within the organisation's own work - National Strategy for the Creation of an Enabling Environment for Civil Society Development from 2012 to 2016, 2012). Šimleša et al. (2015) state that social entrepreneurship manifests in Croatia through three legal entities, which are associations, cooperatives and private limited companies. Croatian legal framework still does not recognize social enterprise as separate legal entity.

The main objective of the Strategy for the Development of Social Entrepreneurship in the Republic of Croatia (Government of the Republic of Croatia 2015; 20) is "creating a supportive environment for the promotion and development of social entrepreneurship in the Republic of Croatia in order to reduce regional differences and ensure employment growth and more just distribution and management of social well-being." Furthermore, the specific objectives of the Strategy are:

a) to establish and improve the legislative and institutional framework for the development of social entrepreneurship;

b) to establish a financial framework for social entrepreneurship;

c) to promote the importance of and the role of social entrepreneurship through formal and informal forms of education;

d) to ensure the visibility of the role and possibilities of social entrepreneurship in Croatia and provide information to the general public.

Social Business Initiative from the European Commission (2011) highlights the three main problems that hinder the development of social entrepreneurship and accordingly three mayor key actions divided in eleven key actions. The first problem for social enterprises is certainly a difficulty of finding funds. Thus, the first major key action is a) Improving access to funding. The second problem is low degree of recognition of social entrepreneurship. Therefore, the second major key action is b) Increasing the visibility of social entrepreneurship. Third problem is that social entrepreneurship is often not defined and it does not mean the same from country to country especially when we are talking about regulatory environment at European and national level. Accordingly, third major key action is c) Improving the legal environment. Specific objectives of Croatian National Strategy are complying with three major key actions from Social Business Initiative.

Measures and activities of the Strategy are included in the Operational Programme Efficient Human Resources 2014 - 2020 (European Social Fund) under the specific objective 9.v.1 Increasing the number and viability of social enterprises and 
their employees, with an allocation of EUR 32 million or EUR 37,647,058.82 when national co-financing is included (Government of the Republic of Croatia 2015).

Table 2: Overview of the financial part of the Strategy for the Development of Social Entrepreneurship in the Republic of Croatia (all amounts in HRK)

\begin{tabular}{|c|c|c|c|c|c|}
\hline \multirow[b]{2}{*}{ Activity } & \multicolumn{5}{|c|}{ Measure } \\
\hline & $\begin{array}{c}\text { Defining and } \\
\text { Development } \\
\text { of Legislative } \\
\text { and Institutional } \\
\text { Framework for } \\
\text { Social Entrepreneurs }\end{array}$ & $\begin{array}{l}\text { Improving the } \\
\text { Availability } \\
\text { of Financial } \\
\text { Instruments } \\
\text { Intended for Social } \\
\text { Entrepreneurs }\end{array}$ & $\begin{array}{l}\text { Promotion of } \\
\text { Education on the } \\
\text { Importance and } \\
\text { Role of Social } \\
\text { Entrepreneurship }\end{array}$ & $\begin{array}{c}\text { Promotion of } \\
\text { Public Visibility } \\
\text { and Recognition } \\
\text { of Social } \\
\text { Entrepreneurship }\end{array}$ & $\begin{array}{l}\text { Monitoring of } \\
\text { the Strategy } \\
\text { Implementation } \\
\text { (Including } \\
\text { Evaluation) }\end{array}$ \\
\hline 1. & $3,000,000.00$ & $24,000,000.00$ & $4,000,000.00$ & $4,000,000.00$ & $100,000.00$ \\
\hline 2. & $300,000.00$ & $40,000,000.00$ & $18,000,000.00$ & $2,000,000.00$ & - \\
\hline 3. & $200,000.00$ & $8,000,000.00$ & $6,000,000.00$ & $2,000,000.00$ & $300,000.00$ \\
\hline 4. & $400,000.00$ & $45,000,000.00$ & $32,000,000.00$ & $6,500,000.00$ & \\
\hline 5. & $100,000.00$ & $43,850,000.00$ & $2,000,000.00$ & $2,000,000.00$ & \\
\hline 6. & $2,400,000.00$ & & $3,000,000.00$ & & \\
\hline 7. & $3,500,000.00$ & & $6,000,000.00$ & & \\
\hline 8. & $2,000,000.00$ & & $2,000,000.00$ & & \\
\hline 9. & $6,000,000.00$ & & $2,000,000.00$ & & \\
\hline SUM & $7,900,000.00$ & $160,850,000.00$ & $75,000,000.00$ & $16,500,000.00$ & $400,000.00$ \\
\hline
\end{tabular}

Source: Government of the Republic of Croatia $(2015 ; 43)$

As we can see from the presented table above, financial part of the Strategy is divided in five measures that are in the accordance with specific objectives of the Strategy. First and third measures Defining and Development of Legislative and Institutional Framework for Social Entrepreneurs and Promotion of Education on the Importance and Role of Social Entrepreneurship both have nine activities which is the maximum while the fifth measure Monitoring of the Strategy Implementation (Including Evaluation) has prescribed the smallest number of activities of all measures - three activities. 
Figure 1: Share of each measure in the total amount of grant

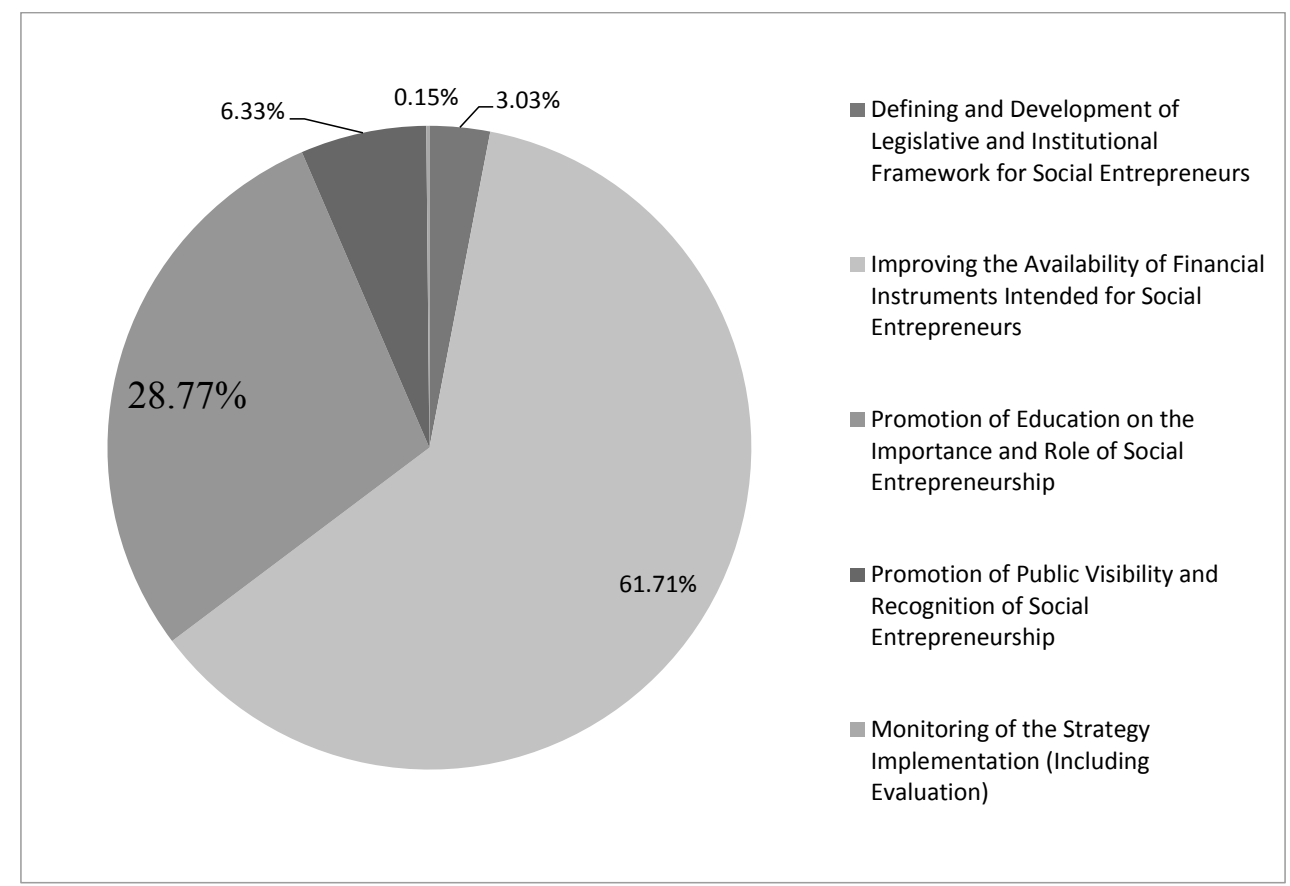

Source: Author's creation based on Government of the Republic of Croatia (2015)

Measure Improving the Availability of Financial Instruments Intended for Social Entrepreneurs has the highest share in the total amount of grant (61.71\%). This measure should improve access to funding for social entrepreneurs because the most social entrepreneurs are faced with the problems of financing their social-entrepreneurial ventures. The second largest sum is intended to measure Promotion of Education on the Importance and Role of Social Entrepreneurship (28.77\%). Perić \& Delić (2014) in their paper emphasize that students in Croatia are not familiar with the concept of social entrepreneurship and its role. Also, there is an insufficient attention given to social entrepreneurship in the educational programmes of faculties and universities. The implementation of activities planned for this measure should remedy the aforementioned problem. The other three measures were given lesser funding, together less than $10 \%$ of the total sum. 


\section{Conslusion}

Social entrepreneurship is still in phase of infancy in the Croatia. However, adopting the Strategy for the Development of Social Entrepreneurship in the Republic of Croatia (2015 to 2020) is certainly a step forward in strategic development of social entrepreneurship. The major problem of Strategy is the delay in implementation of activities. For instance, activity Establishing a unique Social Entrepreneurs Register still has not been executed although the set implementation date was 2nd Quarter of 2016. Because of that, the exact number of social enterprises in Croatia is unknown. Thus, the creation of the Social Entrepreneurs Register must be a priority. There is currently no specific law defining or regulating social enterprise in Croatia and the next step after implementation of planned measures and activities should be to consider of creation institutional and legal framework for new legal entity - social enterprise as new strategic impulse in strengthening the developing position of social entrepreneurship in Croatia.

\section{REFERENCES}

Abu-Saifan, S. (2012). Social Entrepreneurship: Definition and Boundaries. Technology Innovation Management Review, February 2012: Technology Entrepreneurship, 22-27. Retrieved from http://www.timreview.ca/sites/default/files/article_PDF/Saifan_TIMReview_February2012_2.pdf

Ashoka, Retrieved from https://www.ashoka.org/en/ashokas-history; https://www.ashoka.org/en/story/ new-gam

Austin, J., Stevenson, H. \& Wei-Skillern, J. (2006) Social and commercial entrepreneurship: Same, different, or both?, Entrepreneurship Theory and Practice, 30(1), 1-22. DOI: 10.1111/j.15406520.2006.00107.x

Bacq, S. \& Janssen, F. (2011). The multiple faces of social entrepreneurship: A review of definitional issues based on geographical and thematic criteria,. Entrepreneurship \& Regional Development, 23(5-6), 373-403. DOI: 10.1080/08985626.2011.577242

Bayulgen, O. (2008). Muhammad Yunus, Grameen Bank and the Nobel Peace Prize: What Political Science Can Contribute to and Learn From the Study of Microcredit, International Studies Review, 10, 525-547. DOI: 10.1111/j.1468-2486.2008.00803.x

Bornstein, D \& Davis, S (2010). Social Entrepreneurship: What Everyone Needs to Know. New York: Oxford University Press.

Choi, N. \& Majumdar, S. (2014). Social entrepreneurship as an essentially contested concept: Opening a new avenue for systematic future research. Journal of Business Venturing, 29(3), 363-376. DOI: 10.1016/j.jbusvent.2013.05.001

Dees, J. G. (2001). The meaning of "Social Entrepreneurship". Comments and suggestions contributed from the Social Entrepreneurship Founders Working Group. Durham: Center for the Advancement of Social Entrepreneurship, Fuqua School of Business, Duke University. Retrieved from http://www.caseatduke.org/documents/dees_sedef.pdf 
Di Domenico, M., Haugh, H. \& Tracey, P. (2010). Social Bricolage: Theorizing Social Value Creation in Social Enterprises. Entrepreneurship Theory And Practice, 34 (4), 681-703. DOI: 10.1111/j.1540-6520.2010.00370.x

European Commission. (2011). Social Business Initiative - Creating a favourable climate for social enterprises, key stakeholders in the social economy and innovation. Communication from the Commission to the European Parliament, the Council, the European Economic and Social Committee and the Committee of the Regions COM(2011) 682 final. Brussels: European Commission. Retrieved from http://ec.europa.eu/internal_market/social_business/docs/ COM2011_682_en.pdf

Fowler, A. (2000). NGDOs as a moment in history: Beyond aid to social entrepreneurship or civic innovation? Third World Quarterly, 21(4), 637-654. DOI: 10.1080/713701063

Government of the Republic of Croatia. (2012). National Strategy for the Creation of an Enabling Environment for Civil Society Development from 2012 to 2016. Retrieved from http://www. ohchr.org/Documents/AboutUs/CivilSociety/ReportHC/states/5_Croatia_National\%20Strategy-Civil\%20Society-Croatia-2012-2016-eng.pdf

Government of the Republic of Croatia. (2014). Strategy for Combating Poverty and Social Exclusion in the Republic Croatia from 2014 to 2020. Retrieved from https://vlada.gov.hr/UserDocsImages/ZPPI/Strategije/STRATEGY_COMBATING_POVERTY_SOCIAL_EXCLUSION_2014_2020.pdf

Government of the Republic of Croatia. (2015). Strategy for the Development of Social Entrepreneurship in the Republic of Croatia for the period from 2015 to 2020. Retrieved from http://www. esf.hr/wordpress/wp-content/uploads/2015/02/Strategija-razvoja-dru\%C5\%A1tvenog-poduzetni\%C5\%A1tva-u-RH-za-razdoblje-2015-2020.pdf

ICF Consulting Services (2014) A map of social enterprises and their eco-systems in Europe, Country Report: Croatia. Brussels: European Commission. Retrieved from http://ec.europa.eu/social/ BlobServlet?docId=12991\&langId=en

Lasprogata, G. A. \& Cotten, M. N. (2003). Contemplating enterprise: The business and legal challenges of social entrepreneurship. American Business Law Journal, 41(1), 67-113. DOI: 10.1111/ j.1744-1714.2003.tb00002.x

Leadbeater, C. (1997). The rise of the social entrepreneur. London: Demos.

Mair, J. \& Marti, I. (2006). Social entrepreneurship research: A source of explanation, prediction, and delight. Journal of World Business, 41(1), 36-44. DOI: 10.1016/j.jwb.2005.09.002

Nicholls, A. (2006). Social entrepreneurship: New models of sustainable social change. New York: Oxford University Press.

Nobel Prize, The Official Web Site of the Nobel Prize. Retrieved from http://www.nobelprize.org/ nobel_prizes/peace/laureates/2006/yunus-bio.html

OECD (2010). Social entrepreneurship and social innovation. In SMEs, entrepreneurship and innovation. OECD studies on SMEs and entrepreneurship, 185-215, Paris: OECD Publishing. Retrieved from http://ec.europa.eu/internal_market/social_business/docs/conference/oecd_ en.pdf

Peredo, A. M. \& McLean, M. (2006). Social entrepreneurship: A critical review of the concept. Journal of World Business, 41(1), 56-65. DOI: 10.1016/j.jwb.2005.10.007

Perić, J. \& Delić, A. (2014). Social entrepreneurship in Croatia: Do regional disparities influence young people's perception of social entrepreneurship as a potential career path? Ekonomski vjesnik/ Econviews, XXVII (1), 81 - 92. Retrieved from https://hrcak.srce.hr/file/188672

Schwab Foundation. Retrieved from http://www.schwabfound.org; http://www.schwabfound.org/content/what-social-entrepreneur 
Slaper, T. F. \& Hall, T. J. (2011). The Triple Bottom Line: What Is It and How Does It Work?, Indiana Business Review, 86 (1), 4-8. Retrieved from http://www.ibrc.indiana.edu/ibr/2011/spring/ pdfs/article2.pdf

Smith, B. R. \& Stevens C. E. (2010). Different types of social entrepreneurship: The role of geography and embeddedness on the measurement and scaling of social value, Entrepreneurship \& Regional Development, 22 (6), 575-598. DOI: 10.1080/08985626.2010.488405

Sunley, S. \& Pinch, S. (2012). Financing social enterprise: social bricolage or evolutionary entrepreneurialism?, Social Enterprise Journal, 8 (2), 108-122. DOI: 10.1108/17508611211252837

Šimleša, D., Bušljeta Tonković, A. \& Puđak, J. (2016). Društveno poduzetništvo u Hrvatskoj: od prepoznavanja do primjene. Revija za sociologiju, 46 (3), 271-295. DOI: 10.5613/rzs.46.3.2

Šimleša, D., Puđak, J., Majetić, F. \& Bušljeta Tonković, A. (2015). Mapping New Horizons - report on the state of social entrepreneurship in Croatia 2015. Zagreb: Institute of Social Science Ivo Pilar. Retrieved from http://www.pilar.hr/images/stories/dokumenti/razno/projekti/simlesa/ mapping_new_horizons.pdf

Škrtić, M. \& Mikić, M. (2006). Poduzetništvo. Zagreb: Sinergija.

Thompson, J. L. (2008). Social enterprise and social entrepreneurship: where have we reached? A summary of issues and discussion points, Social Enterprise Journal, 4 (2), 149-161. DOI: $10.1108 / 17508610810902039$

Urbano, D., Ferri, E., Peris-Ortiz, M. \& Aparicio S. (2017). Social Entrepreneurship and Institutional Factors: A Literature Review. In: M. Peris-Ortiz, F. Teulon and D. Bonet-Fernandez (Eds.), Social Entrepreneurship in Non-Profit and Profit Sectors - Theoretical and Empirical Perspectives, International Studies in Entrepreneurship 36, 1st ed. (1-29). Cham: Springer International Publishing AG,

Vidović, D. \& Baturina, D. (2016). Social Enterprise in Croatia: Charting New Territories, ICSEM Working Papers, No. 32, Liege: The International Comparative Social Enterprise Models (ICSEM) Project. Retrieved from https://www.iap-socent.be/sites/default/files/Croatia\%20 -\%20Vidovic\%20\%26\%20Baturina_0.pdf

Weerawardena, J. \& Mort, G. S. (2006). Investigating social entrepreneurship: A multidimensional model, Journal of World Business, 41(1), 21-35. DOI: 10.1016/j.jwb.2005.09.001

Wulleman, M. \& Hudon, M. (2016). Models of Social Entrepreneurship: Empirical Evidence from Mexico, Journal of Social Entrepreneurship, 7 (2), 162-188. DOI: 10.1080/19420676.2015.1057207

Yunus, M., Moingeon, B. \& Lehmann-Ortega, L. (2010). Building Social Business Models: Lessons from the Grameen Experience, Long Range Planning, 43 (2-3), 308-325. DOI: 10.1016/j. lrp.2009.12.005

Zahra, S., Gedajlovic, E., Neubaum, D. O. \& Shulman, J. M. (2009). A typology of social entrepreneurs: Motives, search processes and ethical challenges. Journal of Business Venturing, 24 (5), 519-532. DOI: 10.1016/j.jbusvent.2008.04.007 